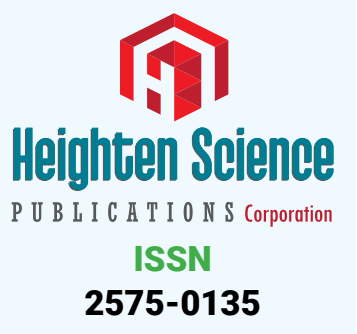

2575-0135

\title{
Assessing the stand size of bay trees (Persea spp.) after exposure to laurel wilt disease in a North Florida Preserve
}

\author{
Anthony M Rossi* and Christopher Bentzien \\ Department of Biology, University of North Florida, Jacksonville, Florida, USA
}

*Address for Correspondence: Anthony $\mathrm{M}$ Rossi, Department of Biology, University of North Florida, Jacksonville, Florida, 32224, USA, Tel: (904) 620-1934; (904)-620-2830;

Email: arossi@unf.edu

Submitted: 09 May 2019

Approved: 03 June 2019

Published: 04 June 2019

Copyright: () 2019 Rossi AM, et al. This is an open access article distributed under the Creative Commons Attribution License, which permits unrestricted use, distribution, and reproduction in any medium, provided the original work is properly cited

Check for updates

\section{Abstract}

Although laurel wilt disease was first reported in the United States in 2002 from redbay trees (Persea borbonia) around Savannah, Georgia it has rapidly spread throughout the southeastern coastal plain including Georgia and Florida. In the current study, transects were used to assess the spread and impact of the disease on two native bay trees redbay ( $P$. borbonia) and swampbay (P. palustris) from north Florida in a semi-naturalized ecological preserve. Although tree size and mortality rates have been reported previously, this study provides the first size-based static life tables for both species. While a significantly higher percent $(76 \%)$ of swampbay trees exhibited signs of laurel wilt disease compared to redbay trees (62\%); redbay had more of its canopy damaged by the disease ( $41 \%$ vs. $32 \%$ for redbay vs. swampbay respectively); this resulted in a significantly smaller stem diameter for $P$. borbonia compared to swampbay, both species are experiencing significant declines due to the disease. Both species exhibited a Type III survivorship curve in which the vast majority of individuals were in the smallest size class (average stem diameter was only 2.5 and $3.6 \mathrm{~cm}$ for redbay and swampbay respectively). Although traditionally, population age (or size) structure that is heavily biased toward younger or smaller size classes suggests that the population is likely to expand in the future, for these bay trees high mortality rate due to beetle/fungal infestation of larger size classes is responsible for this trend; the smallest size classes are largely free from beetle infestation and laurel wilt disease because the stem diameter is likely insufficient to support beetle development. Results from this study suggest that swampbay is also highly susceptible to laurel wilt disease and its populations are likely to exhibit a similar (albeit slower) decline in Florida's wetland and mesic ecosystems.

\section{Introduction}

Laurel wilt disease is a generally fatal infection caused by a non-native fungus (Raffaelea lauricola) that is spread from tree to tree by the exotic redbay ambrosia beetle (RAB) (Xyleborus glabratus). Trees are inoculated with the fungus during gallery formation by adult beetles; females lay eggs in these galleries and the beetle larvae feed on the fungal hyphae - eventually fungal growth plugs the water-conducting xylem vessels of the plant causing the leaves to brown and wilt; typically, the tree will eventually die from the infection $[1,2]$. Unlike leaf abscission in which the leaves develop a characteristic abscission zone and change color (as chlorophyll production ceases and secondary pigments such as carotenoids and anthocyanins become visible) and they are retained on the stem by the vascular tissue until wind or abrasion causes them to drop, laurel wilt kills the leaf by restricting its water supply causing the leaf to brown and die on the stem [3]. Infected trees respond to the fungus by producing tyloses and gums, which may reduce the spread of inections thoughout the plant, but they also inhibit the ability of the vessels to transport water [2]. For instance, tyloses are ballon-like swellings produced by parenchyma cells that project though pit cavities 
in the vessel wall and partially or completely obstruct the vessel [3]. Progression of the disease is easily recognizable by the whole-sale browning of leaves that remain attached to the affected branches as well as the appearance of frass (referred to as sawdust tubes) created by beetle feeding which forms plugs or sticks visible on the external surface of the trees.

Xyleborus glabratus transports the fungus in its mycangia, which are small specialized pouches that are associated with the mandibles $[2,4]$. Recent studies comparing fungi collected from the mycangia of RAB using molecular data and culturing medium that is selective to members of the Ophiostomatales, including $R$. lauricola, are consistent with populations from Southeast Asia [4,5]. Specifically, fungal isolates from the mycangia of X. glabratus populations trapped in U.S. were similar to those from Taiwan and Japan; moreover, bacterial communities from $X$. glabratus mycangia collected in the U.S. were distinctly different from those of native species of xyleborine beetles, but similar to those from Asia $[4,6]$. These results are consistent with the hypothesis that within the U.S. both the beetle and its fungal symbionts were introduced into the U.S. from Asia; most likely via wooden pallets or packing materials that entered through Port Wentworth, which is part of the greater Savannah, Georgia metropolitan area, in the late 1990's or early 2000's [7-10].

Not surprisingly, introduced laurel species such as camphortree (Cinnamomum camphora), which are susceptible to laurel wilt, but are indigenous to southeast Asia and whose native distribution overlaps with that of $\mathrm{RAB}$, have developed resistance to the disease $[10,11]$. For instance, camphor tree, which has become naturalized in the U.S., has shown signs of laurel wilt disease (e.g. browning of leaves and branch dieback), but affected trees typically recover from laurel wilt disease [10]. Laurel wilt has the potential to cause both ecological and economic damage because the laurel family of trees includes both non-commercial native trees such as redbay (Persea borbonia) and swampbay (P. palustris), but also economically important species such as avocado ( $P$. americana). While loss of a commercial product such as avocado is relatively easy to estimate, ecological impacts of declining native bay trees is more problematic; redbay in particular is an important food plant for native animals such as the Palamedes swallowtail butterfly $[5,12,13]$.

In the approximately two decades since its introduction to the U.S. laurel wilt disease has spread rapidly throughout the Southeastern U.S., especially along its primary east-coast interstate highway (I-95) which likely facilitates spread of the beetle and fungus via commercial deliveries along this busy traffic corridor [14]. During 2005 $\mathrm{RAB}$ and the fungus were first reported causing laurel wilt disease in redbay trees in north Florida from Timucuan Ecological and Historic Preserve, Duval County which includes the Jacksonville metropolitan region [5,8]. Fraedrich et al. [15], conducted a detailed study of redbay trees with a dbh $>2.5 \mathrm{~cm}$ within the preserve and found that percentage of cumulative mortality increased from approximately 10 to over $90 \%$ during a 16-month period and larger diameter trees died more quickly than those from smaller size class. Additionally, a 2008 study conducted in St. Johns County (just south of Duval County) of the state-listed endangered laurel tree, pondspice (Litsea aestivalis), reported $85 \%$ of the pondspice trees were already dead or dying from the disease [16]. Although southward spread of the beetle and the concomitant fungus was estimated at 20-30 miles (32-48 km) per year; the beetle was detected in central Florida coastal counties including Indian River and Brevard counties in 2005 and 2006 respectively and south Florida counties including Dade (which includes the Miami metropolitan area) in 2010 some five years sooner than predicted [9,14].

Goals of this project were: 1 ) determine the extent of the disease affecting the two most common species of bay trees (i.e. P. borbonia and P. palustris) on the University of North Florida (UNF) campus (as part of the university's land management strategy); 2) determine if the tree is infesting swampbay as well as redbay; 3) determine the effect of the disease on tree survival and size class. 


\section{Methods}

\section{Study site}

The campus of UNF is situated on approximately 526 ha and includes the Sawmill Slough Preserve which consists of about 121 ha of semi-naturalized habitat that includes ecosystems ranging from pine uplands to mesic forest and hydric wetlands. Although the campus was originally part of a large slash pine plantation, once it was acquired by the state for the site of UNF, it has been left largely undeveloped (except for local construction projects) and undisturbed for at least 70 years. It was not until 2009 that the university finally initiated prescribed burns to thin the vegetation and clear out decades of ladder fuels that had accumulated during this period.

\section{Transects}

During spring 2010, ten 50-m transects were established throughout the wetlands and mesic hammocks of the UNF campus which includes the Sawmill Slough Preserve. Within the larger UNF campus, the Sawmill Slough Preserve was established to create a refuge and provide protection for flora and fauna native to northeastern Florida. Along each transect line, all bay trees (both redbay and swampbay) that fell within 0.5 $\mathrm{m}$ of either side of the transect line were identified to species using tree field guides including dichotomous keys [17-20]. Percent damage to each tree caused by laurel wilt disease was estimated by the browning of the leaf canopy or crown to the nearest $5 \%$ and trunk diameter for each tree was measured to the nearest $0.1 \mathrm{~cm}$ at a height of approximately $50 \mathrm{~cm}$ above the soil surface using digital calipers or a tape measure (note: diameter at breast height [dbh], which is normally measured for tree diameter, was not used in this study because many of the bay tree seedlings (or suckers) were too short to reach this semi-standard height). It should be noted that trees were not cored to determine their age because the trees, which were stressed from the disease, are located in a nature preserve and pemission could not be obtained by the preserve manager to take cores as it was concluded that this might hasten their decline. However, it should be noted that tree diameter and age are typically highly correlated [21,22], although this relationship may become non-linear under some conditions and/or ages for some species [23]. To determine the effect of the disease on the tree survival and size, trees were partitioned into $10-\mathrm{cm}$ size classes to determine which size classes are most susceptible and resistant to infection.

\section{Data analysis}

For each tree species, standard size-based life tables were created and this data were used to generate survivorship curves for both species. Life table parameters included: $\mathrm{x}=$ size class (representing $10-\mathrm{cm}$ size classes); $\mathrm{n}_{\mathrm{x}}=$ number of trees alive at the start of size class $x ; d_{x}=$ number of trees dying between size class $x$ to $x+1 ; l_{x}=$ proportion of the initial population alive at the start of size class $x ; p_{x}=$ proportion of trees that survive size class $x$ to $x+1 ; q_{x}=$ proportion of trees dying during size class $x$ to $\mathrm{x}+1\left(\mathrm{p}_{\mathrm{x}}+\mathrm{q}_{\mathrm{x}}=1\right.$ for any size class $) ; \mathrm{L}_{\mathrm{x}}=$ average number of individuals alive during size class $x$ to $x+1$ (used to calculate average life expectancy); $T_{x}=$ cumulative sum of the $L_{x}$ values for a given size class to the end of the life table (also used to calculate average life expectancy for trees in any size class); $\mathrm{e}_{\mathrm{x}}=$ average life expectancy (in size classes). Additionally, mean tree diameter and percent damage owing to laurel wilt disease were compared using t-tests. Although variances were not significantly different for mean tree diameter, variances for percent damage could not be equalized and, as a result, a t-test for non-equal variances was used for this variable. Lastly, overall rates of the disease in the two bay tree species were compared with a chi-square test using a $2 \times 2$ contingency table with bay tree species and presence or absence of beetle damage (note: because this resulted in a chi-square test with $\mathrm{df}=1$, the test statistic was adjusted using Yates' correction). 


\section{Results}

A total of 558 trees (232 redbay and 326 swampbay) were assessed for damage caused by laurel wilt disease. While tree populations for both species exhibited a large range of sizes (up to $50 \mathrm{~cm}$ and $70 \mathrm{~cm}$ for redbay and swampbay, respectively), the size-class structures of the UNF populations were heavily biased towards the smallest trunk diameters. For instance, approximately $89 \%$ and $79 \%$ of redbay and swampbay trees respectively were in the smallest size class (Tables 1,2). Mean tree diameter for both species was small (mean + sem) of $2.5+0.4 \mathrm{~cm}$ and $3.6+0.5 \mathrm{~cm}$ for redbay and swampbay respectively; this difference was not significant $(\mathrm{t}=1.070 ; \mathrm{p}=.119 ; \mathrm{df}=$ 556; Figure 1).

Thus, populations of both species were highly biased toward the smallest diameters resulting in life tables and Type III survivorship curves that are more typical of invertebrate populations than established tree populations. For both species, life expectancy increased if trees survived the high mortality of the first size class (Tables 1,2). No mature, healthy trees (i.e. free from laurel wilt) were encountered for either species. Thus, trees in the largest size classes, while not completely killed by the disease, were clearly in decline and unlikely to survive the infestation; they were simply so large that they had not completely succumbed to laurel wilt at the time of the survey. The largest disease-free (asymptomatic) trunk diameter was $0.5 \mathrm{~cm}$ and $7.1 \mathrm{~cm}$ for redbay and swampbay, respectively, and both species exhibited generalized Type III survivorship curves (i.e. high mortality in the smallest or youngest size classes with reduced mortality rates in the largest and oldest size classes; Figures 1,2). Mean canopy damage due to laurel wilt disease was high for both species (41\% and 32\% for redbay and swampbay respectively; Figure 1) and this difference was statistically significant $(\mathrm{t}=9.932 ; \mathrm{df}=414.08 ; \mathrm{p}=.002)$. Although significantly fewer $\left(\chi^{2}=12.654 ; \mathrm{p}\right.$ $<.001 ; \mathrm{df}=1)$ redbay trees $(23 \%)$ were asymptomatic for RAB and laurel wilt disease compared to $38 \%$ of swampbay trees this trend was largely driven by the very small diameter of the remaining redbay trees which appear inadequate for RAB oviposition and development.

\section{Discussion}

Although laurel wilt disease was only introduced to U.S. in the last 15-20 years, it has rapidly spread throughout the southeastern states including Georgia and Florida; besides redbay and swampbay, laurel wilt has spread to other native members of

Table 1: Size-class based life table for redbay (Persea borbonia) in the Sawmill Slough Preserve (UNF); see text for details.

\begin{tabular}{|c|c|c|c|c|c|c|c|c|}
\hline Size class $\mathbf{x})$ & $\mathbf{n}_{\mathbf{x}}$ & $\mathbf{d}_{\mathbf{x}}$ & $\mathbf{I}_{\mathbf{x}}$ & $\mathbf{p}_{\mathbf{x}}$ & $\mathbf{q}_{\mathbf{x}}$ & $\mathbf{L}_{\mathbf{x}}$ & $\mathbf{T}_{\mathbf{x}}$ & $\mathbf{e}_{\mathbf{x}}$ \\
\hline $0(0-9.99)$ & 232 & 213 & 1 & 0.082 & 0.918 & 125.5 & 142 & 0.612 \\
\hline $1(10-19.99)$ & 19 & 15 & 0.082 & 0.211 & 0.789 & 11.5 & 16.5 & 0.868 \\
\hline $2(20-20.99)$ & 4 & 2 & 0.017 & 0.5 & 0.5 & 3 & 5 & 1.25 \\
\hline $3(30-39.99)$ & 2 & 1 & 0.009 & 0.5 & 0.5 & 1.5 & 2 & 1 \\
\hline $4(40-49.99)$ & 1 & 1 & 0.004 & 0 & 1 & 0.5 & 0.5 & 0.5 \\
\hline $5(50-59.99)$ & 0 & - & 0 & - & - & - & - & - \\
\hline
\end{tabular}

Table 2: Size-class $(\mathrm{cm})$ based life table for swampbay (Persea palustris) in the Sawmill Slough Preserve (UNF); see text for details.

\begin{tabular}{|c|c|c|c|c|c|c|c|c|}
\hline Size class $(\mathbf{x})$ & $\mathbf{n}_{\mathrm{x}}$ & $\mathbf{d}_{\mathrm{x}}$ & $\mathrm{I}_{\mathrm{x}}$ & $\mathbf{p}_{\mathrm{x}}$ & $\mathbf{q}_{\mathrm{x}}$ & $\mathbf{L}_{\mathrm{x}}$ & $\mathrm{T}_{\mathrm{x}}$ & $\mathbf{e}_{\mathrm{x}}$ \\
\hline $0(0-9.99)$ & 326 & 297 & 1 & 0.089 & 0.911 & 177.5 & 230 & 0.706 \\
\hline $1(10-19.99)$ & 29 & 12 & 0.089 & 0.586 & 0.414 & 23 & 52.5 & 1.81 \\
\hline $2(20-20.99)$ & 17 & 6 & 0.052 & 0.647 & 0.353 & 14 & 29.5 & 1.735 \\
\hline $3(30-39.99)$ & 11 & 5 & 0.034 & 0.545 & 0.455 & 8.5 & 15.5 & 1.409 \\
\hline $4(40-49.99)$ & 6 & 4 & 0.018 & 0.333 & 0.667 & 4 & 7 & 1.167 \\
\hline $5(50-59.99)$ & 2 & 1 & 0.006 & 0.5 & 0.5 & 1.5 & 3 & 1.5 \\
\hline $6(60-69.99)$ & 1 & 0 & 0.003 & 1 & 0 & 1 & 1.5 & 1.5 \\
\hline $7(70-79.99)$ & 1 & 1 & 0.003 & 0 & 1 & 0.5 & 0.5 & 0.5 \\
\hline $8(80-89.99)$ & 0 & - & 0 & - & - & - & 0 & - \\
\hline
\end{tabular}



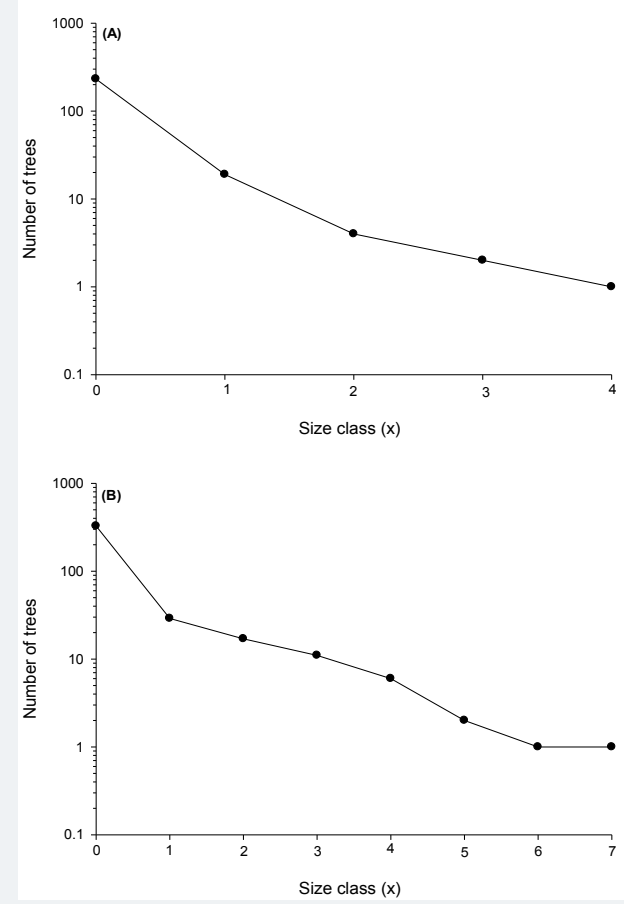

Figure 1: (A) Size-based survivorship curve for (A) redbay (Persea borbonia) and (B) swampbay ( $P$. palustris) from the Sawmill Slough Preserve. Note: each value of $(x)$ represents a 10-cm size class (see text for details).
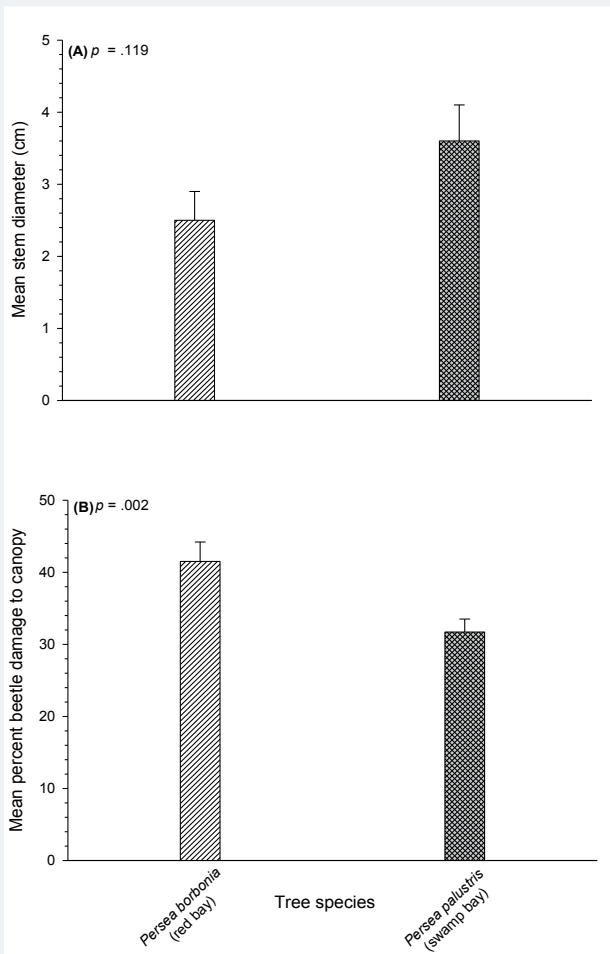

Figure 2: (A) Comparison of mean $(+\mathrm{sem})$ stem diameter $(\mathrm{cm})$ of redbay (Persea borbonia) and swampbay $(P$. palustris) from the Sawmill Slough Preserve $(t=1.070 ; p=.119 ; \mathrm{df}=556)$ and $(B)$ Comparison of mean $(+\mathrm{sem})$ canopy damage caused by laurel wilt disease $(t=9.932 ; d f=414.08 ; p=.002)$.

the Lauraceae including silkbay ( $P$. humilis), sassafras (Sassafras albidium), and pondspice $[1,13,16]$. Results from the current study are consistent with other reports documenting the disease as it infests and moves through an area or ecosystem. Loss of native laurel species may produce cascading effects within an ecosystem; for instance, extirpation of redbay, which is a primary food plant for the Palamedes swallowtail 
(Papilio palamedes) and other lepidopteran species, may indirectly result in their loss. Moreover, laurel wilt has also been detected in non-native laurels such as camphortree and avocado which is an important crop plant (second only to citrus) in Florida $[9,10]$. Avocado is major "export" crop plant for Florida, approximately $85 \%$ of the state's avocado crop is sold outside the state and it provides approximately $\$ 54$ million annually to the state's economy (some $\$ 30$ million to local economy of Dade county alone), and Florida is second only to California for the production of avocado in the U.S. [5,9]. Laurel wilt is firmly established in the U.S. and spread of laurel wilt through native ecosystems and suburban/agricultural landscapes is likely to cause both ecological and economic damage.

However, assessing the long-term effects (both direct and indirect) of laurel wilt on native plant and animal communities as well as ecosystem function is more difficult to determine. Unsurprisingly, emergent diseases such as laurel wilt often spread rapidly among naïve species that have had little or no historical contact with the infectious agent and/or its vector and, as a result, they tend to have little if any resistance to such diseases. Thus, the spread of laurel wilt throughout novel native ecosystems is to be expected and it is consistent with reports of its rapid spread and resultant high mortality to exposed endemic species such as redbay (90\%), sassafras $(80 \%)$ and pondspice (85\%) [2,13]. According to a review by Kendra et al. [14], eleven species of laurel endemic to the U.S. have been identified as hosts of, or susceptible to, laurel wilt disease - and at least two species in Florida, pondspice and pondberry (Lindera melissifolia) are listed by the state/federal government as endangered. Although laurel wilt disease is currently limited to the southeastern U.S. (ranging as far west as Texas and Mississippi according to the U.S. Forest Service), spread of the disease beyond the Rocky mountains to the west coast may pose even greater problems - especially since California is the largest producer of avocados in the country (e.g. approximately 200,000 tons in 2012 alone) [5]. Constant vigilance is required to prevent introduction of this disease to western states and this problem will likely be more difficult because species of laurel native to the west such as California laurel (Umbellularia Californica) have been confirmed as susceptible and identified as potential hosts to the disease, thereby facilitating dissemination of laurel wilt throughout California's ecosystems and agricultural areas $[5,15]$.

Although whole-sale mortality of both redbay and swampbay was extensive within the Sawmill Slough Preserve, swampbay appears to be slightly more resistant to the disease. For instance, the significantly lower rate of infestation of swampbay coupled with its slightly larger trunk diameter suggests that swampbay may be more resistant to the disease or it may take longer to manifest symptoms than redbay. Impact of laurel wilt disease, especially on mature trees, has been extensive resulting in tree populations that are highly biased towards the smallest trunk diameters. These results are consistent with other studies $[1,14]$ that also reported populations of redbay are highly biased toward the smallest trunk diameters. Apparently, these small saplings (or possibly underground suckers attached to the roots of nearby mature trees) are too small for effective colonization of X. glabratus and, hence, spread of the fungus to these diminutive individuals. However, once the trunk or branch diameter of a seedling or sucker exceeds a minimum diameter (the current study suggests a minimum threshold of 0.5 to $1.7 \mathrm{~cm}$ ) the tree becomes vulnerable to X. glabratus infestation. These results are similar to those of Kendra et al. [14], who sampled 830 trees in north-central Florida (Alachua County) and found that trunk diameters $<2 \mathrm{~cm}$ diameter were asymptomatic for laurel wilt disease (the slightly smaller diameter for asymptomatic trees in this study was likely due to the difference in height at which the trunks were measured). In another study, Fraedrich et al. [15], reported that mortality of redbay within the Timucuan Ecological and Historic Preserve with a diameter of $<2.5 \mathrm{~cm}$ was less than $0.5 \%$ ( 1 of 222 trees), however, all redbays with a diameter of greater than $10.3 \mathrm{~cm}$ were dead. In this study, no mature non-infested trees of either redbay or swampbay 
were encountered which suggests that new recruits (i.e. seedlings) will not survive beyond very young (sexually immature) age/size classes, thereby greatly limiting the ability of these bay tree populations to recovery from the disease and replacing dying mature individuals.

\section{Acknowledgement}

This paper was supported by a "SEED" grant from the University of North Florida's Environmental Center awarded to AMR. Special thanks to M. Aspinwall for reviewing the paper prior to submission; their comments improved the clarity of the manuscript. This paper is dedicated to the memory of Gregg Allman (ABB).

\section{References}

1. Snyder JR. Ecological implications of laurel wilt infestation on Everglades tree islands in southern Florida. US Geological Survey Open-file Report. 2014; 1225: 18. Ref.: https://bit.ly/2Kn0tLs

2. Hughes MA, Smith JA, Ploetz RC, Kendra PE, Mayfield AE, et al. Recovery plan for laurel wilt on redbay and other forest species caused by Raffaelea lauricola and disseminated by Xyleborus glabratus. Plant Health Progress. 2011; 16: 173-210. Ref.: https://bit.ly/2Klxk3d

3. Evert RF, Eichhorn SE. Raven Biology of Plants, 8th Edition. Freeman/Palgrave Mcmillan. Ann Bot. 2013; 113: 900. Ref.: http://bit.ly/2WTcpw4

4. Harrington TC, Yun HY, Lu SS, Goto H, Aghayeva DN, et al. Isolations from the redbay ambrosia beetle, Xyleborus glabratus, confirm that the laurel wilt pathogen, Raffaelea lauricola, originated in Asia. Mycologia. 2011; 103: 1028-1036. Ref.: https://bit.ly/2W9sNTG

5. Pisani C, Ploetz RC, Stover E, Ritenour MA, Scully B. Laurel wilt in avocado: Review of an emerging disease. Int J Plant Biol Res. 2015; 3: 1043. Ref.: https://bit.ly/2JWypPI

6. Hulcr J, Rountree NR, Diamond SE, Stelinski LL, Fierer N, et al. Mycangia of ambrosia beetles host communities of bacteria. Microb Ecol. 2012; 64: 784-793. Ref.: https://bit.ly/2wlwWEd

7. Koch FH, Smith WD. Spatio-temporal analysis of Xyleborus glabratus (Coleoptera: Curculionidae: Scolytinae) invasion in eastern U.S. forests. Environ Entomol. 2008; 37: 442-452. Ref.: https://bit.ly/2Z4n7ws

8. Mayfield AE 3rd, Thomas MC. The redbay ambrosia beetle, Xyleborus glabratus Eichhoff (Scolytinae: Curculionidae). 2009; 4. Ref.: https://bit.ly/2Wb4Hbo

9. Evans EA, Crane J, Hodges A, Osborne JL. Potential economic impact of laurel wilt disease on the Florida avocado industry. HortTechnology. 2010; 20: 234-238. Ref.: https://bit.ly/2W5HIUA

10. Fraedrich SW, Harrington TC, Best GS. Xyleborus glabratus attacks and systemic colonization by Raffaelea lauricola associated with diback of Cinnamomum camphora in the southeastern United States. Forest Pathology. 2015; 45: 60-70. Ref.: https://bit.ly/2XvwZ1y

11. Hulcr J, Lou Q. The redbay ambrosia beetle (Coleoptera: Curculionidae) prefers Lauraceae in its native range: records from the Chinese national insect collection. Florida Entomologist. 2013; 96: 1595-1596. Ref.: https://bit.ly/2Xoztii

12. Mayfield AE 3rd, Peña JE, Crane JH, Smith JA, Branch CL, et al. Ability of redbay ambrosia beetle (Coleoptera: Curculionidae: Scolytinae) to bore into young avocado (Lauraceae) plants and transmit the laurel wilt pathogen (Raffaelea sp.). Florida Entomologist. 2008; 91: 485-487. Ref.: https://bit.ly/2HQrNAa

13. Cameron RS, Hanula J, Fraedrich S, Bates C. Progression and impact of laurel wilt disease within redbay and sassafras populations in southeast Georgia. Southeastern Naturalist. 2015; 14: 650-674. Ref.: https://bit.ly/2WdrDXH

14. Kendra PE, Montgomery WS, Niogret J, Epsky ND. An uncertain future for American Lauraceae: a lethal threat from redbay ambrosia beetle and laurel wilt disease (A Review). Am J Plant Sci. 2013; 4: 727-738. Ref.: https://bit.ly/2QFJJAr

15. Fraedrich SW, Harrington TC, Rabaglia RJ, Mayfield AE 3rd, Hanula JL, et al. A fungal symbiont of the redbay ambrosia beetle causes a lethal wilt in redby and other Lauraceae in the southeastern United States. Plant Disease. 2008; 92: 215-224. Ref.: https://bit.ly/2wuZnoX

16. Hughes M, Smith JA, Mayfield AE 3rd, Minno MC, Shin K. First report of laurel wilt disease caused by Raffaelea lauricola on pondspice in Florida. Plant Disease. 2011; 95: 1588-1589. Ref.: https://bit.ly/2lcwUtm 
17. Nelson G. The Shrubs and Woody Vines of Florida. Pineapple Press, Sarasota. 1996; 391. Ref.: https://bit.ly/2liEEKB

18. Duncan WH, Duncan MB. Trees of the Southeastern United States. University of Georgia Press, Athens. 1998; 322. Ref.: https://bit.ly/2WkAl5D

19. Sibley DA. The Sibley Guide to Trees. Knopf, New York. 2009; 427. Ref.: https://amzn.to/2Klpg2x

20. Nelson G, Earle CJ, Spellenberg R. Trees of Eastern North America. Princeton University Press, Princeton. 2014; 720. Ref.: https://bit.ly/2WFmqvM

21. Leak WB. Relationship of tree age to diameter in old-growth northern hardwoods and spruce-fir. United States Department of Agriculture, Research Note NE. 1985; -329: 4. Ref.: https://bit.ly/2KnEOho

22. Lukaszkiewicz J, Kosmala M. Determining the age of streetside trees with diameter at breast height-based mulifactoral model. Agriculture and Urban Forestry. 2008; 34: 137-143. Ref.: https://bit.ly/2WjW1o0

23. Parresol BR, Devall MS. Patterns of diametric growth in stem-analyzed laurel trees (Cordia alliodora) in a Panamanian forest. The Southwestern Naturalist. 2013; 58: 170-178. Ref.: https://bit.ly/313dNut 